\title{
Human CD4+CD25 hiFoxp3+ regulatory T cells are derived by rapid turnover of memory populations in vivo
}

\author{
Milica Vukmanovic-Stejic,, ${ }^{1}$ Yan Zhang, ${ }^{2}$ Joanne E. Cook, ${ }^{1}$ Jean M. Fletcher, ${ }^{1}$ Arthur McQuaid, ${ }^{1}$ \\ Joanne E. Masters, ${ }^{1}$ Malcolm H.A. Rustin, ${ }^{3}$ Leonie S. Taams, ${ }^{4}$ Peter C.L. Beverley, ${ }^{5}$ \\ Derek C. Macallan, ${ }^{2}$ and Arne N. Akbar ${ }^{1}$ \\ 1Department of Immunology and Molecular Pathology, Division of Infection and Immunity, Windeyer Institute of Medical Sciences, University College London, \\ London, United Kingdom. '2 Centre for Infection, Division of Cellular and Molecular Medicine, St. George's, University of London, London, United Kingdom. \\ ${ }^{3}$ Department of Dermatology, Royal Free Hospital, London, United Kingdom. ${ }^{4}$ Department of Immunobiology, King's College London, Guy's Hospital, \\ London, United Kingdom. ${ }^{5}$ Edward Jenner Institute for Vaccine Research, Compton, United Kingdom.
}

\begin{abstract}
While memory $T$ cells are maintained by continuous turnover, it is not clear how human regulatory $\mathrm{CD}^{+} \mathrm{CD}^{2} \mathrm{RO}^{+} \mathrm{CD}^{25 \mathrm{hi}} \mathrm{Foxp}^{+} \mathrm{T}$ lymphocyte populations persist throughout life. We therefore used deuterium labeling of cycling cells in vivo to determine whether these cells could be replenished by proliferation. We found that $\mathrm{CD} 4^{+} \mathrm{CD} 45 \mathrm{RO}^{+} \mathrm{Foxp}^{3+} \mathrm{CD} 25^{\text {hi }} \mathrm{T}$ lymphocytes were highly proliferative, with a doubling time of 8 days, compared with memory $\mathrm{CD}^{+} \mathrm{CD}^{+} 5 \mathrm{RO}^{+} \mathrm{Foxp}^{-} \mathrm{CD}^{-} 5^{-}(24$ days $)$ or naive $\mathrm{CD}^{+} \mathrm{CD} 45 \mathrm{RA}^{+} \mathrm{Foxp}^{-} \mathrm{CD}^{-} 5^{-}$ populations (199 days). However, the regulatory population was susceptible to apoptosis and had critically short telomeres and low telomerase activity. It was therefore unlikely to be self regenerating. These data are consistent with continuous production from another population source. We found extremely close TCR clonal homology between regulatory and memory $\mathrm{CD}^{+} \mathrm{T}$ cells. Furthermore, antigen-related expansions within certain TCR V $\beta$ families were associated with parallel numerical increases of CD $4^{+} C D 45 \mathrm{RO}^{+} \mathrm{CD} 25^{\mathrm{hi}} \mathrm{Foxp}^{+}{ }^{+}$Tregs with the same $V \beta$ usage. It is therefore unlikely that all human $C D 4^{+} \mathrm{CD} 25^{+} \mathrm{Foxp} 3^{+}$Tregs are generated as a separate functional lineage in the thymus. Instead, our data suggest that a proportion of this regulatory population is generated from rapidly dividing, highly differentiated memory $\mathrm{CD}^{+} \mathrm{T}$ cells; this has considerable implications for the therapeutic manipulation of these cells in vivo.
\end{abstract}

\section{Introduction}

Both memory and regulatory populations of T cells must be maintained in tandem in order to generate controlled immunity for the lifetime of the organism. Since the thymus involutes early in life, memory $\mathrm{T}$ cells have to largely be maintained by lifelong turnover of preexisting populations of specific $T$ cells in adults $(1,2)$. The corollary of this is that thymic involution during aging will also severely restrict the production of Tregs by this organ. The source of these cells in adult humans and the relative contributions of long-term survival and ongoing turnover to the maintenance of $\mathrm{CD}^{+} \mathrm{CD} 25^{\text {hi }} \mathrm{Foxp}^{+}$Treg populations remain unknown.

The naturally occurring $\mathrm{CD} 4^{+} \mathrm{CD} 25^{\text {hi }}$ Treg subset that expresses the lineage marker Foxp3 represents an important population of suppressive $\mathrm{T}$ cells that can prevent reactivity to both self and nonself antigens (3-5). These cells also downregulate immune responses as pathogen is cleared (3-5). Early studies demonstrated that in mice, $\mathrm{CD} 4^{+} \mathrm{CD} 25^{\text {hi }}$ Tregs are generated as a distinct population in the thymus (6). Indeed, in mice, there is substantial overlap of TCR repertoires between thymic and peripheral CD $4^{+} \mathrm{Foxp} 3^{+}$ Tregs, suggesting that the thymic regulatory pool makes a significant contribution to the peripheral regulatory cells (7). However, murine $\mathrm{CD} 4^{+} \mathrm{CD} 25^{\text {hi }}$ Tregs, which are phenotypically and functionally identical to the thymus-derived population can also be

Nonstandard abbreviations used: $d^{*}$, disappearance rate constant; $\mathrm{T}_{2}$, doubling time; $p$, proliferation rate constant; PerCP, peridinin-chlorophyll-protein complex. Conflict of interest: The authors have declared that no conflict of interest exists. Citation for this article: J. Clin. Invest. 116:2423-2433 (2006). doi:10.1172/JCI28941. generated after antigen-induced proliferation of $\mathrm{CD}^{+} \mathrm{T}$ cells in peripheral tissues (8-10).

Programmed cell death or apoptosis represents an important control mechanism during the activation and expansion of memory $T$ cells during each reencounter with antigen (11-13). Furthermore, the residual replicative capacity of these cells may be limited by telomere erosion $(14,15)$, which eventually leads to cell cycle arrest and is a mechanism that may limit the proliferative capacity of memory $T$ cells during repeated stimulation with antigen $(14,16)$. Although $C D 4^{+} \mathrm{CD} 25^{\text {hi }}$ Tregs have been shown to divide rapidly in murine systems (17-19), humans have a much longer life span but much shorter telomeres than mice (20). This suggests that the lifelong persistence of human $\mathrm{CD} 4^{+} \mathrm{CD} 25^{\text {hi }}$ Tregs by continuous proliferation may be limited. In addition, if human $\mathrm{CD} 4{ }^{+} \mathrm{CD} 25^{+}$Tregs are produced throughout life and continue to be produced after thymic involution, important questions arise about their clonal origin, particularly whether it is shared with or independent of memory T cells.

In order to investigate the turnover rates of $\mathrm{CD} 4^{+} \mathrm{CD} 25^{+}$Tregs in humans, we used novel stable isotope technology to label proliferating cells with deuterium in vivo. To address the origin of these cells, we also investigated the relationship between the clonality of memory and Tregs by heteroduplex analysis. Collectively, our data show that human $\mathrm{CD} 4^{+} \mathrm{CD} 25^{\text {hi }}$ Tregs do not arise solely from thymic generation but can also be induced by rapid turnover from the memory $T$ cell pool. However, once generated, they are susceptible to apoptosis and have limited replicative potential. This suggests that antigenic persistence will induce continuous generation of 

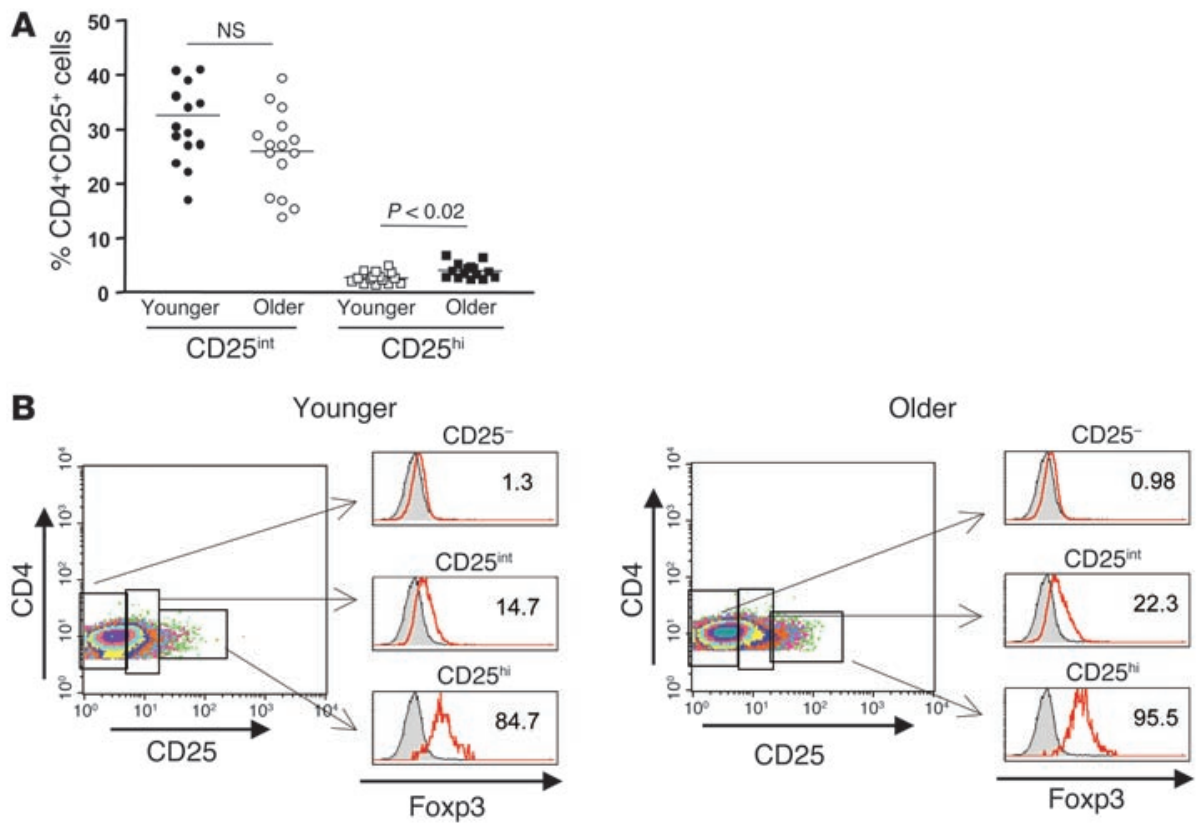

C Anti-CD3
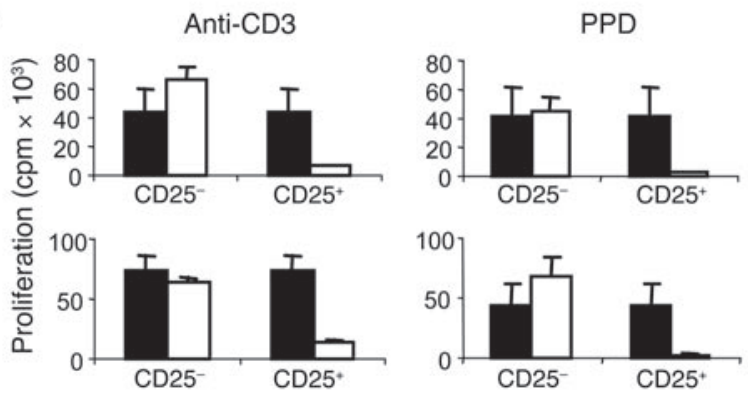

Figure 1

CD4 ${ }^{+}$CD25 ${ }^{+} T$ cells remain functional with age. (A) Freshly isolated PBMCs from younger and older donors were stained with CD4 and CD25 and the percentages of CD25 int and CD25 hi CD4 ${ }^{+} T$ cells were determined. Statistical significance was determined by 2-tailed, unpaired Student's $t$ test. (B) The coexpression of CD25 and Foxp3 in CD4+ T cells in older and younger subjects was determined. The left panels show the gating on PBMCs labeled with CD4-PerCP and CD25-PE. Based on CD25 expression, the CD4 population is subdivided into CD25-, CD25int, and CD25 hi populations. Histograms illustrate the Foxp3 expression in gated populations (log scale). Filled histograms represent staining with secondary antibody alone. Results are representative of 5 separate experiments performed on younger and older subjects. (C) Purified CD4 ${ }^{+}$CD25- $T$ cells were stimulated with immobilized anti-CD3, purified protein derivative (PPD), and tetanus toxoid in the presence of autologous irradiated PBMCs as APCs. CD4 ${ }^{+} \mathrm{CD} 25^{-} \mathrm{T}$ cells were cultured in the absence (black bars) or presence (white bars) of equal numbers of either $C D 4^{+} \mathrm{CD} 25^{-}$or $\mathrm{CD} 4{ }^{+} \mathrm{CD} 25^{+}$cells. Proliferation was measured by ${ }^{3} \mathrm{H}$-thymidine incorporation on day 3 (for anti-CD3) and day 6 (for recall antigens), and results are expressed as mean \pm SEM of triplicate wells. Results shown are representative of 5 experiments performed in younger and older subjects.

antigen-specific Tregs from the responsive population but that, in the absence of antigen, such populations are likely to disappear. This may contribute to maintenance of tolerance toward autologous and dietary antigens in vivo yet allow for subsequent responsiveness to antigens that are encountered intermittently.

\section{Results}

$\mathrm{CD} 4^{+} \mathrm{CD} 25^{+} \mathrm{Foxp}^{+}$Tregs are maintained during aging in humans. If the thymus were the major source of $\mathrm{CD} 4^{+} \mathrm{CD} 25^{+} \mathrm{Foxp}^{+}$Tregs in adults, the number of such cells would be expected to decline with aging. To address this issue we first investigated whether the

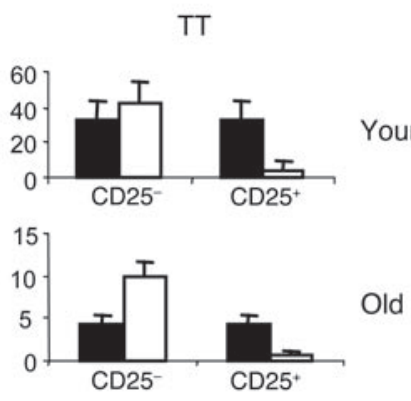

number of $\mathrm{CD} 4^{+} \mathrm{CD} 25^{\text {hi }} \mathrm{T}$ cells was altered in older ( $>70$ years) compared with younger $(<35$ years) subjects. As previous studies have shown that only the $\mathrm{CD}^{+} \mathrm{T}$ cell population with the highest CD25 expression contains Treg activity (21), we used a stringent gating approach as detailed in Methods. We found that $\mathrm{CD} 4^{+} \mathrm{CD} 25^{\text {hi }}$ cells actually constituted a greater proportion of the $\mathrm{CD}^{+} \mathrm{T}$ cell pool in the older subjects (mean $3.8 \%$; $n=15$ ) than in the younger (mean $2.7 \%$; $n=15$ ) (Figure 1A; $P=0.0119$ ).

In addition, we investigated the phenotypic and functional capacity of such cells in younger and older subjects. The $\mathrm{CD} 4^{+} \mathrm{CD} 25^{\text {hi }} \mathrm{T}$ cell populations in both groups were exclusively $\mathrm{CD}_{45 \mathrm{RA}^{-}}$and expressed lower levels of CD45RB (Supplemental Figure 1; supplemental material available online with this article; doi:10.1172/JCI28941DS1) but higher levels of CTLA-4 (data not shown) than $\mathrm{CD}^{+} \mathrm{CD} 25^{-} \mathrm{T}$ cells and were therefore identical qualitatively. Furthermore, CD $4^{+} \mathrm{CD} 25^{\text {hi }}$ cells in both younger and older subjects showed high levels of Foxp3 expression when compared with the $\mathrm{CD}_{4}^{+} \mathrm{CD} 25^{-}$or $\mathrm{CD} 4^{+} \mathrm{CD} 25^{\text {int }}$ populations in the same individuals (Figure 1B). Finally, we compared the functional capacity of $\mathrm{CD} 4^{+} \mathrm{CD} 25^{\text {hi }} \mathrm{T}$ cells from younger and older individuals by stimulating with anti-CD3 and the recall antigens tuberculin purified-protein derivative and tetanus toxoid (TT). When $\mathrm{CD} 4^{+} \mathrm{CD} 25^{\text {hi }} \mathrm{T}$ cells were added in coculture, cells from younger and older subjects showed equivalent suppressive activity on $\mathrm{CD} 4^{+} \mathrm{CD} 25^{-} \mathrm{T}$ cells (Figure 1C). These observations indicated that both the number and functional integrity of naturally occurring $\mathrm{CD}^{+} \mathrm{CD} 25^{\text {hi }}$ Foxp $3^{+}$Tregs are maintained during aging.

Treg turnover in vivo. Since the number of $\mathrm{CD} 4^{+} \mathrm{CD} 25^{\text {hi }}$ Tregs was maintained during aging despite thymic involution, we investigated whether these populations were generated by ongoing proliferation, as opposed to long-term survival, in vivo. Methods have been developed recently that enable the turnover of T lymphocytes to be determined by labeling dividing cells with nonradioactive isotopes in vivo (22-24). In the presence of deuterium-labeled glucose, all metabolic derivatives of glucose became proportion- 


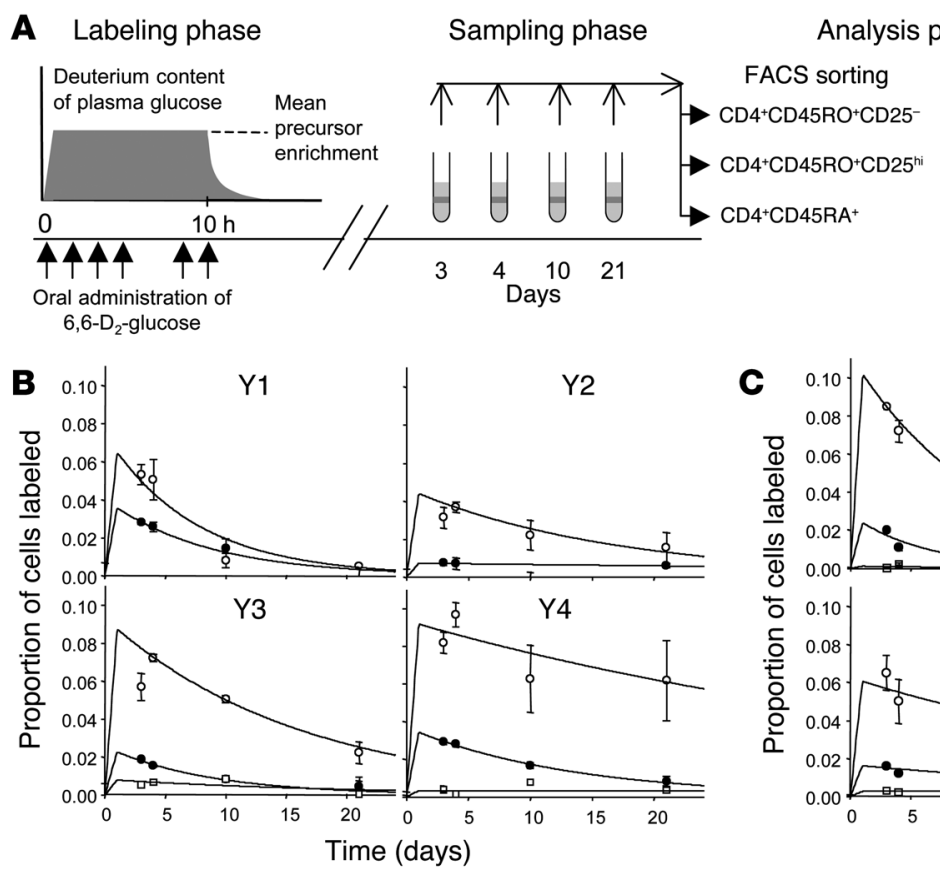

\section{Analysis phase}
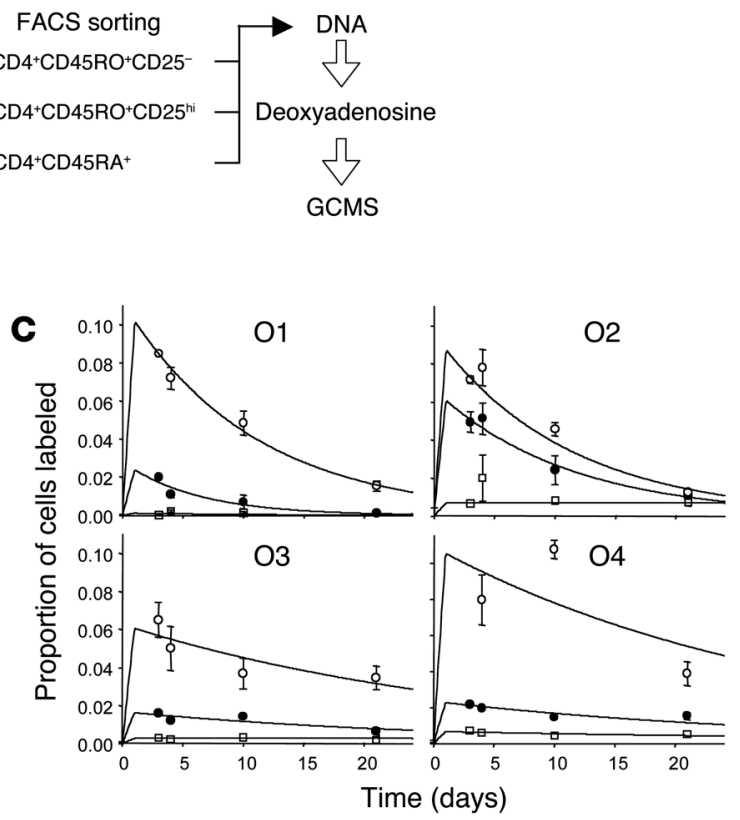

Figure 2

Analysis of in vivo kinetics of human $\mathrm{CD} 4{ }^{+} \mathrm{CD} 25^{\mathrm{hi}} \mathrm{T}$ cells. Outline of protocol is shown in A. Subjects received $0.64 \mathrm{~g} / \mathrm{kg} 6,6-\mathrm{D}_{2}-\mathrm{glucose}$ by halfhourly oral dosing for 10 hours. Blood samples were taken first during labeling, for analysis of deuterium content in plasma glucose, and second after labeling, to determine deuterium content in DNA. (B) Fraction of labeled cells ( $F$, expressed relative to a labeling phase of 1 day) for each sorted cell population from 4 younger subjects $(Y 1-Y 4)$ was determined. Open circles represent $C D 4+C D 45 R O+C D 25$ hi, filled circles represent $\mathrm{CD}^{+} \mathrm{CD} 45 \mathrm{RO}^{+} \mathrm{CD} 25^{-}$, and open squares represent $\mathrm{CD} 4{ }^{+} \mathrm{CD} 45 \mathrm{RA}{ }^{+} \mathrm{T}$ cells. Error bars represent SD of triplicate gas chromatography mass spectrometry (GCMS) measurements (labeling of CD4+CD45RA ${ }^{+} T$ cells was too low to be detectable in individuals $C 16$ and $C 17$ ). Modeled proliferation and disappearance kinetics are best-fit curves as described in Methods. (C) The fraction of labeled cells in sorted T cell populations from 4 older subjects (O1-O2) and curve fits were analyzed and modeled in the same way.

ately labeled; this included deoxynucleosides, whose de novo synthesis pathway incorporates a pentose ring from cellular pentose pools, most of which are derived from glucose (24). Cell populations that divide therefore incorporate deuterium into their DNA in proportion to, first, the number of cell divisions within that population, and second, the level and duration of precursor (glucose) labeling. Nondividing populations remain unlabeled. We used this approach to measure proliferation and disappearance rates of $\mathrm{CD} 4^{+} \mathrm{CD} 45 \mathrm{RO}^{+} \mathrm{CD} 25^{\mathrm{hi}}$ and $\mathrm{CD} 4^{+} \mathrm{CD} 45 \mathrm{RO}^{+} \mathrm{CD} 25^{-}$cells in 4 younger (mean age 25 years) and 4 older subjects (mean age 81 years). Each individual received deuterium-labeled glucose for 10 hours, after which blood samples were taken on days 3, 4, 10 , and $21 ; \mathrm{CD}^{+}{ }^{+} \mathrm{CD} 45 \mathrm{RO}^{+} \mathrm{CD} 25^{\mathrm{hi}}, \mathrm{CD} 4^{+} \mathrm{CD} 45 \mathrm{RO}^{+} \mathrm{CD} 25^{-}$, and $\mathrm{CD}^{+} \mathrm{CD}^{+} 5 \mathrm{RA}^{+}$subsets were isolated by cell sorting as described in Methods (Supplemental Figure 2). Kinetics of labeling in vivo were calculated from the enrichment of deuterium in DNA of sorted $\mathrm{T}$ cell subsets, with higher enrichment indicating a greater portion of dividing cells (Figure 2A). The magnitude of peak labeling, which reflects the rate of proliferation in vivo, was significantly higher in $\mathrm{CD}^{+} \mathrm{CD} 45 \mathrm{RO}^{+} \mathrm{CD} 25^{\text {hi }}$ regulatory cells $(7.44 \%$ of cells labeled) than in $\mathrm{CD}^{+} \mathrm{CD} 45 \mathrm{RO}^{+} \mathrm{CD} 25^{-}$memory cells $(2.41 \%)$ in all 8 individuals tested $(P<0.0005$; Table 1$)$. The enrichment of deuterium in $\mathrm{CD}^{+} \mathrm{CD} 45 \mathrm{RA}^{+}$cells was very low $(0.82 \%$; Figure $2, \mathrm{~B}$ and $\mathrm{C}$, and Table 1), consistent with slow turnover of this population. Similar differences between proliferation rates of different subsets were observed when younger and older groups were analyzed separately (Figure 2, B and C, respectively).
When kinetics of proliferation and death were modeled to yield proliferation and disappearance rate constants ( $p$ and $d^{*}$ ) as previously described $(2,17)$, significant proliferation was observed in the $\mathrm{CD}^{+} \mathrm{CD} 45 \mathrm{RO}^{+} \mathrm{CD} 25^{\mathrm{hi}}$ population (mean $8.31 \%$ /day, equivalent to a doubling time $\left[\mathrm{T}_{2}\right]$ of 8 days), more than in the $\mathrm{CD}^{+}{ }^{+} \mathrm{CD} 45 \mathrm{RO}^{+} \mathrm{CD} 25^{-}$populations $\left(2.43 \%\right.$ /day, $\mathrm{T}_{2}$ of 24 days;

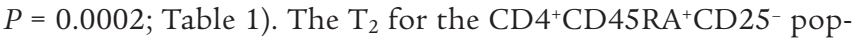
ulation was 199 days. When younger and older groups were analyzed separately, the ranges of values for proliferation of $\mathrm{CD}^{+} \mathrm{CD} 45 \mathrm{RO}^{+} \mathrm{CD} 25^{\text {hi }}$ cells were very similar $(4.54 \%-9.27 \%$ and $6.16 \%-10.7 \% /$ day respectively; $P=0.3$ ). Indeed, there were no significant differences between younger and older subjects in the proliferation rates of any of the cell types analyzed (Table 1). Significant disappearance rates for labeled cells $\left(d^{*}\right)$ were found in the $\mathrm{CD} 4^{+} \mathrm{CD} 25^{\text {hi }}$ population, $6.58 \%$ day, equivalent to a mean half-life of about 11 days, similar to the measured proliferation rate.

Our results suggest that in both younger and older individuals, human Tregs comprise a dynamic population that is continually replaced by proliferation either of $\mathrm{CD} 4^{+} \mathrm{CD} 25^{\text {hi }}$ cells themselves, as observed in mice $(17,18)$, or of $\mathrm{CD}^{+} \mathrm{CD} 25^{-} \mathrm{T}$ cells that proliferate, then rapidly enter the $\mathrm{CD} 25^{\mathrm{hi}}$ pool (within the 3 -day interval between labeling and first blood sampling). Once within the $\mathrm{CD} 4^{+} \mathrm{CD} 25^{\text {hi }}$ pool, these cells are lost rapidly. This explains the relatively constant numbers of $\mathrm{CD} 4^{+} \mathrm{CD} 25^{\text {hi }} \mathrm{T}$ cells throughout life despite such high rates of proliferation.

Constraints on the persistence of $C D 4^{+} C D 25^{\text {bi }}$ Tregs in vivo. Thus, labeling data are most consistent with the continuous generation 
A
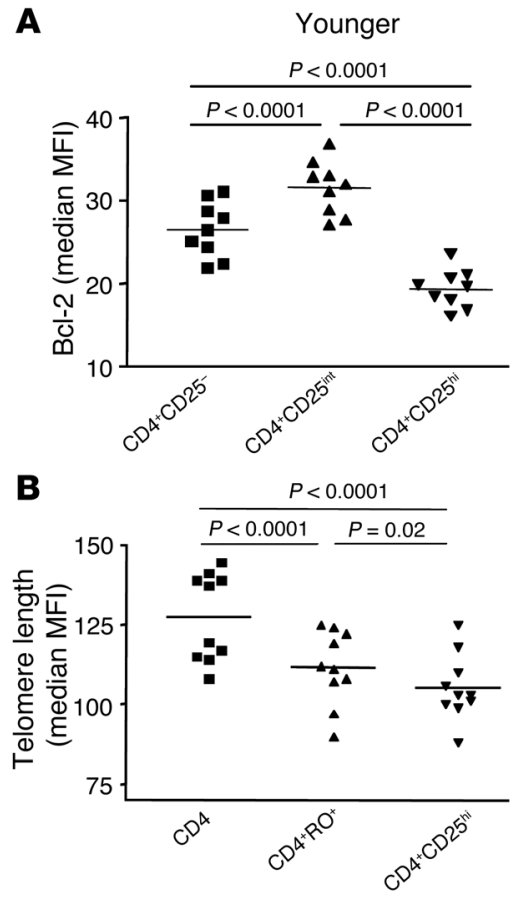
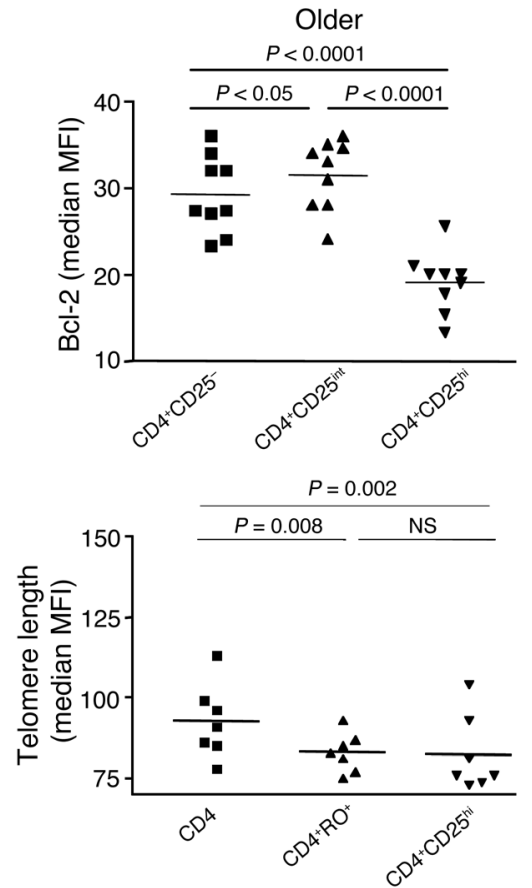

Figure 3

Constraints on $\mathrm{CD} 4{ }^{+} \mathrm{CD} 25^{\text {hi }} \mathrm{T}$ cell maintenance. (A) Based on CD25 expression, the CD4 population was subdivided into CD25-, CD25int, and CD25 hi populations. Bcl-2 expression in each subset was determined by intracellular staining and expressed as median mean fluorescent intensity (MFI). Statistical significance was determined using a 2-tailed, paired Student's $t$ test. (B) CD4 ${ }^{+} C D 25^{\text {hi }}$ $T$ cells have significantly shorter telomeres than total CD4 T cells in both younger and older donors. Telomere length was measured using a 3-color flow-FISH technique. $P$ values were determined by 2-tailed, paired Student's $t$ test. (C) $C D 4+C D 25^{\text {hi }}$ T cells cannot upregulate telomerase. FACS-sorted $\mathrm{CD}^{+}{ }^{+} \mathrm{CD} 45 \mathrm{RO}^{+} \mathrm{CD} 25^{-}$and $\mathrm{CD} 4{ }^{+} \mathrm{CD} 45 \mathrm{RO}^{+}{ }^{+} \mathrm{CD} 25^{\mathrm{hi}}$ cells from younger and older donors were stimulated with anti-CD3/anti-CD28 beads for 4 days. Telomerase activity was measured by a TRAP assay. An equivalent number of proliferating $\left(\mathrm{Ki} 67^{+}\right)$ cells were used in each reaction. The negative control (-cnt) contains the PCR mix without cell extract and the positive control (+ cnt) contains an extract of a telomerase-positive tumor cell line. TSR8 is a telomeric template, used as PCR control.

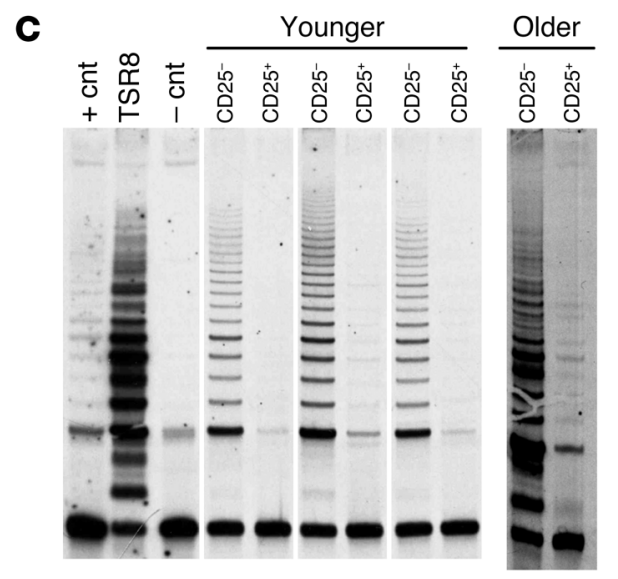

model for the origin of $\mathrm{CD} 4{ }^{+} \mathrm{CD} 25^{\text {hi }}$ Tregs. However, to further investigate the alternative hypothesis that such cells are long lived in vivo, we investigated markers of apoptosis in vivo. Our previous studies have shown that $\mathrm{CD} 4{ }^{+} \mathrm{CD} 25^{+}$Tregs express low levels of the antiapoptotic molecule $\mathrm{Bcl}-2$ and are very susceptible to apoptosis in vitro (25). However, in these early experiments, we gated on the total $\mathrm{CD} 4{ }^{+} \mathrm{CD} 25^{+}$population, which included both nonregulatory $\mathrm{CD} 25^{\text {int }}$ and regulatory $\mathrm{CD} 25^{\text {hi }}$ populations. We have now extended these observations by investigating $\mathrm{Bcl}-2$ expression in $\mathrm{CD}^{+} \mathrm{CD} 45 \mathrm{RO}^{+} \mathrm{CD} 25^{\mathrm{hi}}, \mathrm{CD} 4^{+} \mathrm{CD} 45 \mathrm{RO}^{+} \mathrm{CD} 25^{\text {int }}$, and $\mathrm{CD} 4{ }^{+} \mathrm{CD} 45 \mathrm{RO}^{+} \mathrm{CD} 25^{-}$populations, using a more stringent gating strategy (as described in Figure 1B). In both younger and older donors, Bcl-2 expression was significantly lower in the CD25 hi subsets. The very strong correlation between $\mathrm{Bcl}-2$ expression and death in T cells (26-28) suggests that these cells are unlikely to persist because of resistance to apoptosis in vivo (Figure 3A).

Telomere length provides an indication of both replicative history and replicative potential within a population. Each cell division leads to the loss of 50-100 bp of telomeric DNA due to the inability of DNA polymerase to replicate fully the ends of chromosomes (29). In the absence of the enzyme telomerase, this eventually leads to cell cycle arrest due to telomere erosion and is a mechanism that may limit the proliferative capacity of $\mathrm{T}$ cells $(14,16)$. Using a recently developed 3 -color Flow-FISH technique, we compared the relative telomere length in $\mathrm{CD} 4^{+} \mathrm{CD} 25^{\mathrm{hi}}$ $\mathrm{T}$ cells in younger and older subjects and compared them with telomere lengths of total $\mathrm{CD}^{+}$and $\mathrm{CD}^{+}{ }^{+} \mathrm{CD} 45 \mathrm{RO}^{+}$populations. $\mathrm{CD} 4^{+} \mathrm{CD} 25^{\text {hi }} \mathrm{T}$ cells had significantly shorter telomeres than the total $\mathrm{CD}^{+} \mathrm{T}$ cell population in the same subjects $(P=0.002$ in older and $P<0.0001$ in younger; Figure $3 \mathrm{~B})$. In the younger donors, $\mathrm{CD} 4^{+} \mathrm{CD} 25^{\text {hi }} \mathrm{T}$ cells also had significantly shorter telomeres than the total $\mathrm{CD} 4{ }^{+} \mathrm{CD} 45 \mathrm{RO}^{+}$primed/memory $\mathrm{CD} 4 \mathrm{~T}$ cell subset $(P=0.02)$. Using standard curves to equate relative telomere length determined by Southern blot to relative telomere length as determined by flow-FISH $(30,31)$, we showed that the mean telomere length in $\mathrm{CD} 4^{+} \mathrm{CD} 25^{\text {hi }}$ cells was $5.7 \mathrm{~kb} \pm 0.8 \mathrm{~kb}$ (mean $\pm \mathrm{SD}$ ) and $4 \mathrm{~kb} \pm 0.8 \mathrm{~kb}$ in younger and older individuals, respectively (Supplemental Figure 3). Although there appears 
A $\quad V_{\beta} 11$

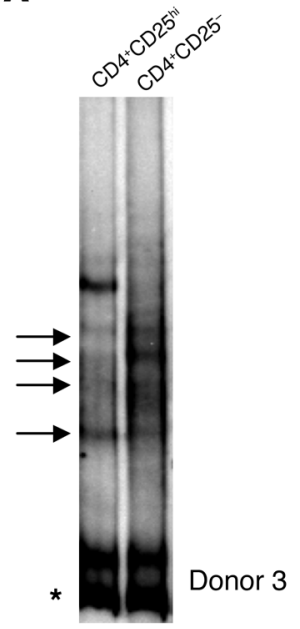

B

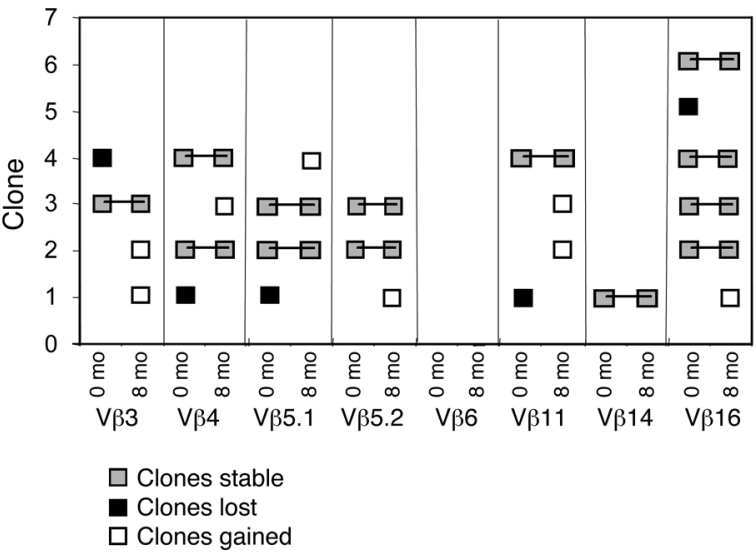

\section{C}

Donor 7

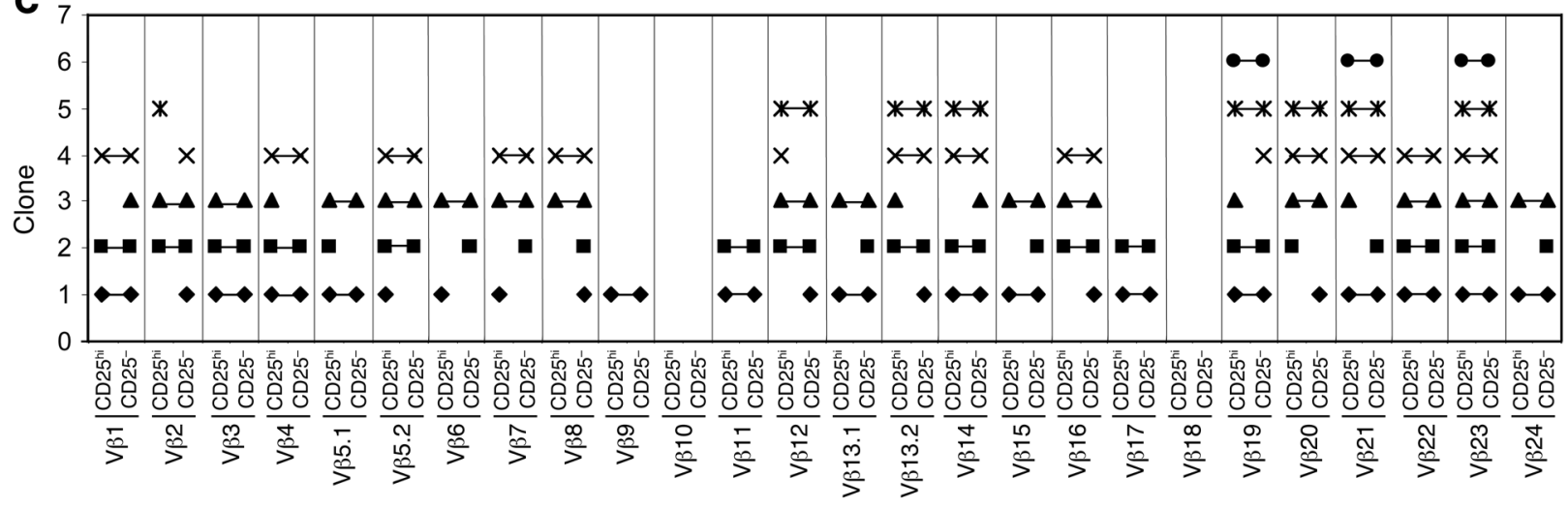

\section{Figure 4}

Regulatory $\mathrm{CD} 4{ }^{+} \mathrm{CD} 25^{\text {hi }} \mathrm{T}$ cells are closely related to effector $\mathrm{CD} 4{ }^{+} \mathrm{T}$ cells. CD4+CD25 hi and $\mathrm{CD} 4{ }^{+} \mathrm{CD} 25^{-}$cells were $\mathrm{FACS}$ sorted as before, and heteroduplex analysis was performed for $26 \mathrm{~V} \beta$ families. (A) Heteroduplex analysis of $C D 4^{+} C D 25^{-}$and $C D 4{ }^{+} C D 25^{\text {hi }}$ cells showing a representative $\mathrm{V} \beta$ family from 1 out of the 7 volunteers that were investigated. Solid arrows on the left of the blot indicate clonal bands that are present in both subsets. The asterisk indicates the position of the carrier homoduplexes. The schematic representation of the distribution of clones present in $\mathrm{CD} 4{ }^{+} \mathrm{CD} 25^{-}$and $\mathrm{CD} 4{ }^{+} \mathrm{CD} 25^{\text {hi }}$ subpopulations across the $26 \mathrm{~V} \beta$ families in 1 individual is shown in $\mathbf{B}$, where the presence of a clone in a particular $\mathrm{V} \beta$ family for either subset is represented by a symbol and a clone that is shared between the 2 subsets is represented by a line joining 2 symbols. (C) Schematic representation of the clones present in CD4+CD25 hopulation from 1 donor at different time points taken 7 months apart.

to be a biphasic distribution of telomere length within the $\mathrm{CD} 4^{+}$ population of younger subjects, this was not observed when a larger cohort of younger subjects was analyzed (32).

To determine whether $\mathrm{CD} 4^{+} \mathrm{CD} 25^{\text {hi }} \mathrm{T}$ cells were able to maintain their telomeres without further erosion upon activation, we studied their ability to upregulate telomerase upon stimulation in vitro. $\mathrm{CD}^{+}{ }^{+} \mathrm{CD} 45 \mathrm{RO}^{+} \mathrm{CD} 25^{\mathrm{hi}}$ and $\mathrm{CD} 4^{+} \mathrm{CD} 45 \mathrm{RO}^{+} \mathrm{CD} 25^{-} \mathrm{T}$ cells were stimulated in vitro with anti-CD3- and anti-CD28-coated beads in the presence of high doses of IL-2 $(200 \mathrm{U} / \mathrm{ml})$ for 4 days. Under these conditions, $\mathrm{CD} 4^{+} \mathrm{CD} 25^{\text {hi }} \mathrm{T}$ cells were capable of limited expansion in vitro at a considerably lower level than the CD25- population (data not shown). To ensure a fair comparison, the telomerase activity analysis always included an equivalent number of proliferating $\mathrm{CD} 25^{\mathrm{hi}}$ and $\mathrm{CD} 25^{-} \mathrm{T}$ cells. $\mathrm{CD} 4^{+} \mathrm{CD} 25^{\mathrm{hi}}$ cells failed to upregulate telomerase compared with CD25- T cells in both younger and older subjects (Figure 3C).

Previous studies have shown that in the absence of telomerase activity, telomeres shorten by $50-100$ bp with every cell division and replicative senescence occurs when telomeres shorten to below $4 \mathrm{~kb}(14,16)$. Combining the telomere and turnover data, since $\mathrm{CD} 4{ }^{+} \mathrm{CD} 25^{\text {hi }} \mathrm{T}$ cells from younger subjects have a mean telomere length of $5.7 \mathrm{~kb}$ and a mean doubling time of 9 days (Table 1), these cells are predicted to reach senescence within 2 years. With telomeres already approaching critical length $(4 \mathrm{~kb})$ and a mean doubling time of 8 days, $\mathrm{CD} 4^{+} \mathrm{CD} 25^{\text {hi }} \mathrm{T}$ cells in the older subjects are already approaching senescence. The high rate of proliferation of $\mathrm{CD} 4^{+} \mathrm{CD} 25^{\text {hi }} \mathrm{T}$ cells yet only modest increase in the number of these cells during aging suggests that rapid proliferation is balanced by equally rapid cell loss, and this is evident in the calculated rate of death in the cell turnover studies (Table 1).

The deuterium-labeling studies are unable to distinguish between loss of cells from the circulation due to death and that due to migration into tissues or phenotypic conversion. A major role for migration seems unlikely because of the early appearance in blood of recently divided $\mathrm{CD} 4{ }^{+} \mathrm{CD} 45 \mathrm{R} 0^{+} \mathrm{CD} 25^{\text {hi }} \mathrm{T}$ cells (within 3 days; Figure 2) and the absence of late reappearance of labeled 


\section{Table 1}

In vivo proliferative kinetics of CD4+ T cells defined according to levels of CD25 expression

\begin{tabular}{|c|c|c|c|c|c|c|c|c|c|c|c|}
\hline \multirow[b]{2}{*}{ Subjects } & \multicolumn{4}{|c|}{ CD4+CD45RO+CD25- } & \multicolumn{4}{|c|}{$\mathrm{CD} 4+C D 45 R 0+C D 25^{\mathrm{hi}}$} & \multicolumn{3}{|c|}{$\mathrm{CD}^{+}{ }^{+C D} 45 \mathrm{RA}^{+}$} \\
\hline & Peak (\%) & $p$ (\%/day) & $\mathrm{T}_{2}$ (day) & $d^{*}(\% /$ day $)$ & Peak (\%) & $p$ (\%/day) & $\mathrm{T}_{2}$ (day) & $d^{*}(\% /$ day $)$ & Peak (\%) & $p(\% /$ day $)$ & $\mathrm{T}_{2}$ (day) \\
\hline \multicolumn{12}{|l|}{ Younger } \\
\hline Y1 & 2.82 & 3.81 & 18 & 11.8 & 5.35 & 6.97 & 10 & 13.4 & ND & 0 & $>$ \\
\hline Y2 & 0.76 & 0.75 & 92 & 1.09 & 3.69 & 4.54 & 15 & 6.01 & ND & 0 & $>$ \\
\hline Y3 & 1.87 & 2.41 & 29 & 11.6 & 7.24 & 9.02 & 8 & 6.20 & 0.84 & 0.69 & 100 \\
\hline Y4 & 2.92 & 3.56 & 19 & 7.55 & 9.68 & 9.27 & 7 & 2.04 & 0.78 & 0.34 & 204 \\
\hline Mean & 2.09 & 2.63 & 26 & 8.02 & 6.49 & 7.45 & 9 & 6.92 & 0.81 & 0.26 & 267 \\
\hline \multicolumn{12}{|l|}{ Older } \\
\hline 01 & 2.01 & 2.59 & 27 & 16.2 & 8.48 & 10.7 & 6 & 9.26 & 0.22 & 0.12 & 578 \\
\hline 02 & 5.14 & 6.38 & 11 & 9.02 & 7.79 & 9.13 & 8 & 9.06 & 2.01 & 0.69 & 100 \\
\hline 03 & 1.58 & 1.64 & 42 & 3.65 & 6.51 & 6.16 & 11 & 3.26 & 0.33 & 0.26 & 267 \\
\hline 04 & 2.16 & 2.3 & 30 & 3.35 & 10.8 & 10.7 & 6 & 3.35 & 0.73 & 0.68 & 102 \\
\hline Mean & 2.72 & 3.23 & 21 & 8.05 & 8.38 & 9.17 & 8 & 6.23 & 0.82 & 0.44 & 158 \\
\hline \multicolumn{12}{|c|}{ All subjects $(n=8)$} \\
\hline Mean & $2.41^{\mathrm{A}}$ & $2.93^{B}$ & $24 c$ & 8.04 & $7.44^{\mathrm{D}}$ & $8.31^{\mathrm{E}}$ & $8^{F}$ & 6.58 & $0.82^{\mathrm{G}}$ & $0.35^{\mathrm{H}}$ & 198 \\
\hline SD & 1.3 & 1.7 & NA & 5.13 & 2.29 & 2.21 & NA & 3.83 & 0.64 & 0.3 & NA \\
\hline
\end{tabular}

Peak represents maximal enrichments expressed as fraction of new (dividing) cells relative to a labeling period of 1 day; $p$ and $d^{\star}$ are modeled as described in Methods. >, greater than the upper limit of evaluation; ND, no enrichment detected; because of the very low proliferative rate of CD4 ${ }^{+}$CD45RA ${ }^{+}$ cells, $d^{*}$ for this cell type was zero or not evaluable and is not shown. $\mathrm{A}, \mathrm{D}, \mathrm{G} P<0.05 ; \mathrm{B}, \mathrm{E}, \mathrm{H} P<0.01$; ${ }^{\mathrm{C}, \mathrm{F}, \mathrm{I} P}<0.001$ after log transformation; comparisons by ANOVA with post hoc Tukey-Kramer test.

cells in the blood. Phenotypic conversion also appears unlikely since no contemporaneous increase of labeling in other $\mathrm{CD}^{+}$ subsets was observed. Furthermore, the suggestion that the rapid loss of labeled cells was primarily due to cell death is more consistent with the observed low Bcl-2 expression (Figure 3A) and high susceptibility of $\mathrm{CD} 4^{+} \mathrm{CD} 45 \mathrm{R} 0^{+} \mathrm{CD} 25^{\text {hi }} \mathrm{T}$ cells to apoptosis (25). The similar disappearance rate of $\mathrm{CD}^{+} \mathrm{CD} 45 \mathrm{R} 0^{+} \mathrm{CD} 25^{-} \mathrm{T}$ cells ( $d^{*}$ of $8.04 \% /$ day) relative to the $\mathrm{CD} 25^{\text {hi }}$ regulatory population ( $d^{*}$ of $6.58 \% /$ day) is consistent with a similar heightened susceptibility to apoptosis of the subpopulation of actively dividing memory cells (12). Since the rapid proliferation of $\mathrm{CD} 4^{+} \mathrm{CD} 25^{\text {hi }}$ $\mathrm{T}$ cells is balanced by rapid loss, yet $\mathrm{CD} 4^{+} \mathrm{CD} 25^{\text {hi }} \mathrm{T}$ cells are maintained at constant levels throughout life (Figure 1A), we conclude that these cells represent a transient population that is generated continuously in vivo.

\section{Table 2}

Clonal homology between CD4+CD25 hi Tregs and CD4+CD25memory T cells

$\begin{array}{lc}\text { Donor } & \text { \% Clones shared } \\ 1 & 58.3 \\ 2 & 87.5 \\ 3 & 78.2 \\ 4 & 90.0 \\ 5 & 89.5 \\ 6 & 79.4 \\ 7 & 79.3 \\ \text { Mean } & 80.3\end{array}$

CD4 ${ }^{+} \mathrm{CD} 25^{\text {hi }}$ Tregs and $\mathrm{CD} 4{ }^{+} \mathrm{CD} 25^{-}$- memory $T$ cells from 7 donors were FACS sorted as before and analyzed by HDA. Percentage of clones shared between $\mathrm{CD}^{+}{ }^{+} \mathrm{CD} 25^{-}$and $\mathrm{CD} 4{ }^{+} \mathrm{CD} 25^{\text {hi }}$ subpopulations in all 7 donors tested. Percentages were calculated as follows: (total number of clones shared in $\mathrm{CD} 4{ }^{+} \mathrm{CD} 25^{+}$and $\mathrm{CD} 4{ }^{+} \mathrm{CD} 25$-/total number of clones in $\left.\mathrm{CD}^{+}{ }^{+} \mathrm{CD}^{-} 5^{-}\right) \times 100$.
Regulatory $C D 4^{+} C D 25^{\text {hi }}$ and memory $C D 4^{+} C D 25^{-} \mathrm{T}$ cells are derived from the same clonal precursors. The observation that $\mathrm{CD} 4^{+} \mathrm{CD} 25^{\mathrm{hi}}$ Tregs are unlikely to be maintained throughout life by their own continuous proliferation raised questions about the origin of the precursor population for these cells. Since memory and Tregs have to be maintained in parallel throughout life, we investigated whether these cells were derived from the same or different clonal precursor populations. When we compared the TCR repertoires of $\mathrm{CD} 4{ }^{+} \mathrm{CD} 45 \mathrm{RO}^{+} \mathrm{CD} 25^{\text {hi }}$ and $\mathrm{CD} 4{ }^{+} \mathrm{CD} 45 \mathrm{RO}^{+} \mathrm{CD} 25^{-}$populations, there was striking similarity in the breadth of $\mathrm{V} \beta$ usage between the 2 subsets (Supplemental Figure 4).

We extended these studies by investigating the clonal relationship between $\mathrm{CD}^{+} \mathrm{CD} 45 \mathrm{RO}^{+} \mathrm{CD} 25^{\text {hi }}$ and $\mathrm{CD} 4{ }^{+} \mathrm{CD} 45 \mathrm{RO}^{+} \mathrm{CD} 25^{-}$ $T$ cell populations within each of 26 different $V \beta$ families in the same individuals by heteroduplex analysis (Figure 4 and Table 2). Previous studies have shown that sharing of a clonal band by 2 different cell populations within a V $\beta$ family indicates that the cells that give rise to the band are expanded in vivo and are derived from a precursor with the same antigenic specificity $(31,33)$. In 7 individuals tested, a mean of $80 \%$ of clonal bands present was shared between expanded memory and $\mathrm{CD}^{+}{ }^{+}$Tregs (Table 2), showing close clonal homology, which indicated that they were most likely derived from the same precursor populations. Furthermore, when we compared the clonal distribution of $\mathrm{CD}^{+} \mathrm{CD} 45 \mathrm{RO}^{-} \mathrm{CD} 25^{\mathrm{hi}}$ $\mathrm{T}$ cells from 1 individual that were isolated at 2 different time points 7 months apart, we found that, although $33 \%$ of the clones were new and $12.5 \%$ of the clones had been lost, $60 \%$ of the clones persisted (Figure 4C). Thus, the picture that emerges is one of dynamic clonal evolution within the subset over time with lineages of $\mathrm{CD}^{+}$Tregs developing that are closely related to those within the $\mathrm{CD}^{+} \mathrm{CD} 45 \mathrm{RO}^{+} \mathrm{CD} 25^{-}$memory $\mathrm{T}$ cell pool.

These results suggest that antigen-driven expansion of $\mathrm{CD} 4^{+} \mathrm{T}$ cells would induce the production of $\mathrm{CD} 4^{+} \mathrm{CD} 45 \mathrm{RO}^{+} \mathrm{Foxp}^{+} \mathrm{CD} 25^{\mathrm{hi}}$ Tregs. To confirm this, we investigated younger and older individuals with persistent CMV infection, who developed large expansions 

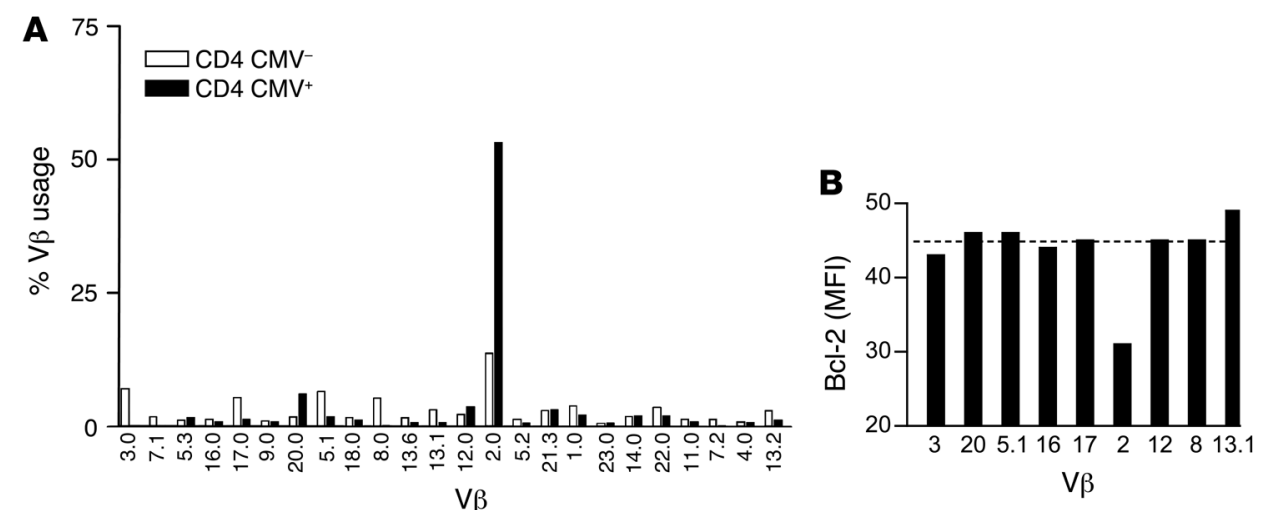

C

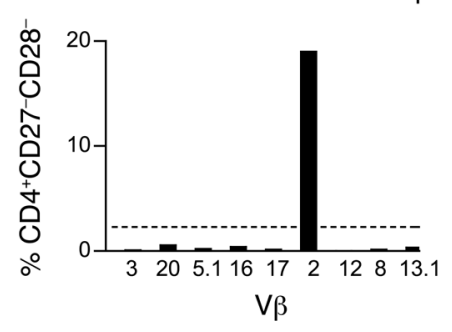

D

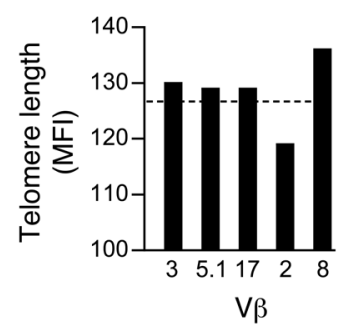

E
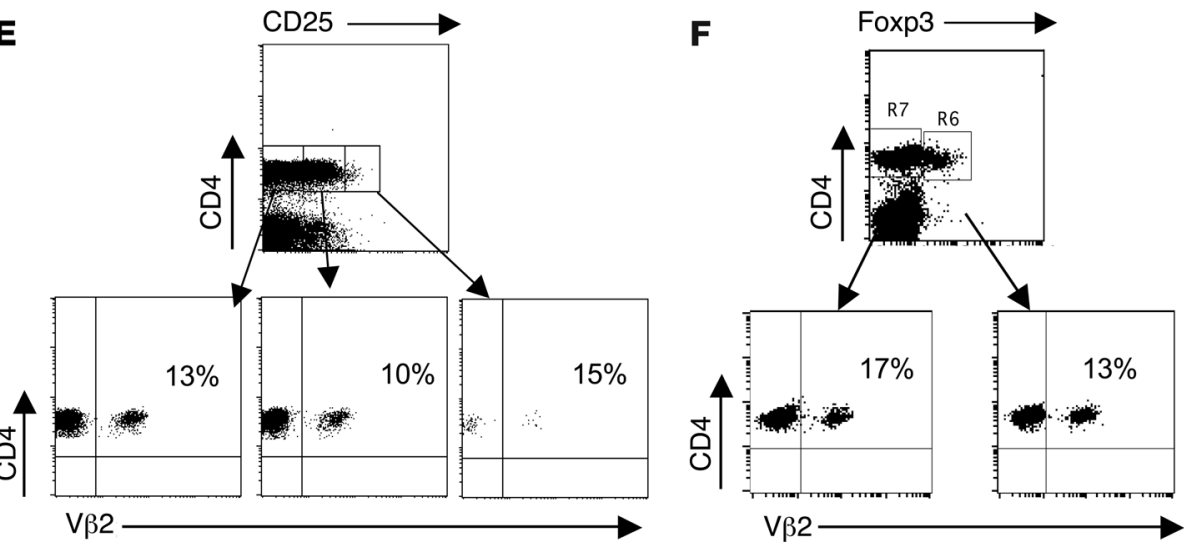

Figure 5

Antigen-driven expansion of CD4+ $\mathrm{T}$ cells is associated with concomitant expansion within the CD4+CD45RO+Foxp3 ${ }^{+}$CD25 hi Treg population. (A) PBMCs from a CMV seropositive donor were stimulated with CMV lysate and CMV-specific CD4+ $4^{+}$cells identified by IFN- $\gamma$ secretion. TCR V $\beta$ usage of the total $\mathrm{CD}^{+}$(open bars) and CD4+IFN- $\gamma^{+}$T cells (black bars) was analyzed by costaining with 24 different anti-TCR V $\beta$ antibodies. (B) PBMCs from the same donor were then stained with CD4, Bcl-2, and a range of $\mathrm{V} \beta$-specific antibodies. (C) $C M V$-specific $C D 4^{+} \mathrm{V} \beta 2^{+} \mathrm{T}$ cell population was largely CD27-CD28- compared with other $\mathrm{V} \beta \mathrm{s}$. (D) CD4+ $\mathrm{V} \beta 2^{+} \mathrm{T}$ cell population has short telomeres relative to other less-expanded $\mathrm{V} \beta$ families. Telomere length was determined using 3-color flow-FISH. (E) Similar expansions in V $\beta 2 \mathrm{~T}$ cell population were found in CD4 ${ }^{+} \mathrm{CD} 25^{-} \mathrm{CD} 4{ }^{+} \mathrm{CD} 25^{\text {int }}$ and $\mathrm{CD} 4{ }^{+} \mathrm{CD} 25^{\mathrm{hi}}$ subsets. The top panel shows fresh PBMCs gated on the basis of CD4 and CD25 expression as before. Bottom panels show the proportion of cells expressing $\mathrm{V} \beta 2$ in each of the subsets defined by CD25 expression. These data are representative of 3 experiments. (F) Similar expansions in V $\beta 2 T$ cell population were found in $\mathrm{CD}^{+}{ }^{+} \mathrm{Foxp}^{-}$and $\mathrm{CD} 4^{+} \mathrm{Foxp} 3^{+}$subsets. Fresh PBMCs were gated on the basis of CD4 and Foxp3 expression (top panel), and proportion of cells expressing V $\beta 2$ in each subset is indicated (bottom panels). These data are representative of 3 experiments. telomeres (Figure 5D) relative to other less-expanded $V \beta$ families. This is consistent with previous observations that CMV-specific $\mathrm{CD}^{+} \mathrm{T}$ cells in both younger and older subjects were highly differentiated and susceptible to apoptosis (32). This strongly suggested that the $\mathrm{CD}^{+} \mathrm{V}^{+} 2^{+}$expansion in this subject was likely to be induced by extensively differentiated CMVspecific $\mathrm{CD}^{+} \mathrm{T}$ cells $(15,32)$ rather than selective $V \beta$ family usage that may be genetically determined in this individual. We found that $1.5 \%-2.0 \%$ of the total $\mathrm{CD}^{+} \mathrm{T}$ cell population in this subject was CD $4{ }^{+} \mathrm{CD} 45 \mathrm{RO}^{+} \mathrm{Foxp}^{+} \mathrm{CD} 25^{\text {hi }}$, a value in the same range as that of the cohort of individuals previously tested (Figure 1A). The expanded $\mathrm{CD}^{+}{ }^{+} \mathrm{V} \beta 2^{+} \mathrm{T}$ cell population was not only found in the $\mathrm{CD} 4^{+} \mathrm{CD} 25^{-}$and $\mathrm{CD} 4{ }^{+} \mathrm{CD} 25^{\text {int }}$ cells but was also highly represented in the $\mathrm{CD}^{+} \mathrm{CD} 45 \mathrm{RO}^{+} \mathrm{CD} 25^{\mathrm{hi}}$ population and constituted $15 \%$ of these cells (Figure 5E). Furthermore, when we examined Foxp3$\mathrm{CD}^{+}$and $\mathrm{Foxp}^{+} \mathrm{CD}^{+} \mathrm{T}$ cells from this individual, we found that the expanded V $\beta 2$ population was found in both fractions (Figure $5 \mathrm{~F}$ ). This further indicates that expansions of memory/effector $\mathrm{CD}^{+}{ }^{+} \mathrm{CD} 45 \mathrm{RO}^{+} \mathrm{Foxp}^{-} \mathrm{CD}^{-} 5^{-}$and $\mathrm{CD} 4{ }^{+} \mathrm{CD} 45 \mathrm{RO}^{+} \mathrm{Foxp}^{+} \mathrm{CD} 25^{\mathrm{hi}}$ Tregs are antigen-driven and related and that they arise in tandem.

\section{Discussion}

The key observations of this study are, first, that human CD $4^{+} \mathrm{CD} 25^{\text {hiF }}{ }^{\text {Foxp }} 3^{+}$Tregs divide rapidly in vivo but have limited capacity for extensive self-renewal, and second, that it is very likely that these cells are continuously recruited from the memory $\mathrm{CD}^{+}$ $\mathrm{T}$ cell pool. These observations are entirely compatible with recent elegant studies in the mouse, in which it has been shown that $\mathrm{CD}^{+} \mathrm{CD} 25^{\text {hiFoxp }} 3^{+} \mathrm{T}$ cells can be of $C M V$-specific $C D 4^{+} \mathrm{T}$ cells within certain $V \beta$ families. In the representative individual referred to in Figure $5 \mathrm{~A}, \mathrm{CMV}$-specific $\mathrm{CD} 4^{+} \mathrm{T}$ cells, identified by IFN- $\gamma$ secretion after stimulation with CMV lysate (32), were largely restricted to the V $\beta 2$ family (Figure $5 \mathrm{~A})$. This $\mathrm{CD}^{+} \mathrm{V} \beta 2^{+} \mathrm{T}$ cell population showed low $\mathrm{Bcl}-2$ expression (Figure 5B), was largely CD27-CD28- (Figure 5C), and had short induced by antigen in the periphery (8-10). However, the considerably different life span of the mouse and human dictate that the constraints imposed on the maintenance of these cells by continuous proliferation in both species will be very different. These differences have to be taken into consideration when attempts are made to manipulate $\mathrm{CD} 4{ }^{+} \mathrm{CD} 25^{\text {hiFoxp }}{ }^{+}$Tregs for therapeutic 
purposes. We find that human $\mathrm{CD} 4^{+} \mathrm{CD} 25^{\text {hiFoxp }} 3^{+} \mathrm{T}$ cells are susceptible to apoptosis through reduced $\mathrm{Bcl}-2$ expression and have limited replicative capacity resulting from poor telomerase inducibility and extensive telomere erosion. These constraints, together with thymic involution, could be expected to result in a reduction in numbers of $\mathrm{CD} 4^{+} \mathrm{CD} 25^{\text {hi }}$ cells with age. Contrary to this, we have confirmed and extended previous reports that proportions of $\mathrm{CD} 4{ }^{+} \mathrm{CD} 25^{\text {hi }}$ Tregs are actually increased in older subjects (34).

The concept that there is inherent plasticity in the functional repertoire of $\mathrm{CD}^{+} \mathrm{T}$ cells is highlighted by the ability to induce different Th1 and Th2 cytokine secretion profiles in the presence of exogenous cytokines (35). The results presented here suggest that there are other points in the $\mathrm{CD}^{+} \mathrm{T}$ cell differentiation pathway where exogenous signals can induce these cells to differentiate into regulatory populations. It has been shown that $\mathrm{CD}^{+} \mathrm{CD} 25^{\text {hiFoxp }} 3^{+}$Tregs can be induced from CD $4^{+} \mathrm{CD} 25^{-}$Foxp $3^{-}$ $T$ cell populations in the presence of TGF- $\beta$ in vivo $(9,36,37)$. In addition to $\mathrm{CD} 4^{+} \mathrm{CD} 25^{\text {hi }} \mathrm{T}$ cells, other regulatory populations, such as IL-10-producing Tr1 (38) and TGF- $\beta$-producing Th 3 cells (39) can also be induced from naive and/or memory CD25- T cells under specific conditions. This suggests that active mediators may direct the development of Treg populations in cellular microenvironments. In addition, $\mathrm{CD} 4^{+}$Tregs can also be induced by specific surface receptor triggering, and we and others have shown previously that the induction of anergy in antigen-specific $\mathrm{CD}^{+} \mathrm{T}$ cell populations induces these cells to become suppressive in vitro (40, 41) and in vivo (42). We extended these observations recently by showing that human memory $\mathrm{CD} 4^{+} \mathrm{T}$ cells isolated from a site of antigenic rechallenge in the skin in vivo (31) could be anergized in vitro and that this induced high levels of Foxp 3 expression and suppressive activity in these cells (data not shown). This is also supported by studies that suggest that some human responsive $\mathrm{CD} 4^{+} \mathrm{CD} 25^{-} \mathrm{T}$ cells undergo a transition into $\mathrm{CD} 4^{+} \mathrm{CD} 25^{\text {hi }}$ Tregs as a natural event after specific activation in vitro (43). Collectively, these data indicate that the perception of the extent to which the functional $\mathrm{CD}^{+} \mathrm{T}$ cell repertoire is flexible should be extended to include the ability of exogenous cues to induce suppressive activity in these cells. In addition, since $\mathrm{CD} 4^{+} \mathrm{CD} 25^{\text {hi }} \mathrm{Foxp}^{+} \mathrm{T}$ cells have been found consistently to have a highly differentiated phenotype, it is likely that the regulatory cues only have an effect on $\mathrm{CD}^{+} \mathrm{T}$ cells that have been activated to proliferate extensively.

Two unresolved questions are whether naturally occurring thymic-derived $\mathrm{CD} 4^{+} \mathrm{CD} 25^{\text {hi }} \mathrm{T}$ cells are identical to $\mathrm{CD} 4^{+} \mathrm{CD} 25^{\text {hi }}$ $\mathrm{T}$ cells that are induced from primed/memory $\mathrm{CD} 4^{+} \mathrm{CD} 25^{-} \mathrm{T}$ cells in the periphery and whether all $\mathrm{CD} 4^{+} \mathrm{Foxp} 3{ }^{+} \mathrm{CD} 25^{\text {hi }}$ Tregs that are induced in different ways are exactly the same. Indeed, the relationship between these and other regulatory $\mathrm{CD} 4^{+}$populations, such as those that secrete IL-10 $(38,44)$, remains to be clarified. However, since $\mathrm{CD} 4^{+} \mathrm{Foxp} 3^{+} \mathrm{CD} 25^{\text {hi }}$ Tregs can be induced by cues that may be present in tissue microenvironments, some of the defects in $\mathrm{CD}^{+}{ }^{+} \mathrm{Foxp}^{+} \mathrm{CD} 25^{\text {hi }}$ Tregs that have been reported in certain diseases (45-48) may be due to aberrant induction and not dysfunction of these cells per se. Furthermore, since the human $\mathrm{CD} 4{ }^{+} \mathrm{CD} 25^{\text {hi }} \mathrm{Foxp}^{+}$ $\mathrm{T}$ cell population is susceptible to apoptosis, infusion of these cells into individuals with various diseases to modulate disease activity may only elicit short-term benefit as they may be cleared rapidly in vivo. In this context, survival factors, such as IL-2, that have been shown to be essential for the generation of $\mathrm{CD} 4^{+} \mathrm{CD} 25^{\text {hi }}$ Foxp $3^{+}$ $T$ cells may be effective in part through their ability to counteract the susceptibility of these cells to apoptosis (49-51). In contrast, the proximity of $\mathrm{CD}^{+} \mathrm{CD} 25^{\text {hiFoxp }} 3^{+} \mathrm{T}$ cells to replicative senescence may be of therapeutic benefit since their capacity for continuous proliferation will be limited in vivo. This would preclude the development of generalized immunosuppression arising from the potential transfer of suppressive activity to other cells (52).

In summary, we show that rapid peripheral turnover is responsible for the maintenance of the human $\mathrm{CD} 4^{+} \mathrm{CD} 25^{\text {hiFoxp }} 3^{+} \mathrm{T}$ cell population during aging. Our observations suggest a model whereby the context of stimulation of a memory $\mathrm{CD} 4^{+} \mathrm{T}$ cell population in peripheral tissues leads to the generation of $\mathrm{CD} 4^{+}$Tregs, which are relatively short-lived. This would promote immune resolution yet permit future responses to subsequent antigenic challenge. Such a model links the extent of regulation induced during an immune response to the level of antigenic stimulation. Such linkage may be part of the mechanism whereby peripheral tolerance to persistent antigens is achieved (32). Furthermore, these data highlight the potential of persistent infections with viruses, such as CMV, that drive the continuous lifelong differentiation of specific $\mathrm{CD}^{+}$ $\mathrm{T}$ cells (32) to induce the generation of $\mathrm{CD} 4^{+} \mathrm{CD} 25 \mathrm{hiFoxp}^{+} \mathrm{T}$ cells. Such processes may contribute to the immune defect that is well documented in older subjects $(15,53)$.

\section{Methods}

Subjects. Healthy younger ( $<35$ years) and older ( $>70$ years) individuals were recruited from volunteers at University College London and St. George's, University of London. In total, 27 younger (mean age 27, range 21-34) and 31 older volunteers (mean age 78, range 70-90) were recruited into the study. Subjects diagnosed with active disease or using any medication thought to affect immune function were excluded. For the glucose labeling and turnover analysis, 4 younger (mean age 25, range 21-31; 2 males/ 2 females) and 4 older subjects (mean age 81, range 76-85; 3 males/ 1 female) were recruited for the study. All provided written informed consent to protocols approved by local ethics committees, and study procedures were performed in accordance with the principles of the World Medical Association Declaration of Helsinki.

Magnetic purification of the T cell subsets from peripheral blood. PBMCs were isolated by density centrifugation on Ficoll-Paque PLUS (Amersham Biosciences), and $\mathrm{CD}^{+} \mathrm{T}$ cells were isolated by negative selection using the CD4 isolation kit for magnetic separation (Miltenyi Biotec) according to the manufacturer's instructions. $\mathrm{CD} 4^{+} \mathrm{T}$ cells were incubated with mouse anti-human CD25 MicroBeads ( $2 \mu \mathrm{l} / 10^{7}$ cells; Miltenyi Biotec) and separated into $\mathrm{CD}^{+} \mathrm{CD} 25^{+}$and $\mathrm{CD} 4^{+} \mathrm{CD} 25^{-} \mathrm{T}$ cells on a positive selection column (LS; Miltenyi Biotec). CD4 ${ }^{+} \mathrm{CD} 25^{-}$fraction was then reincubated with CD25 MicroBeads $\left(20 \mu \mathrm{l} / 10^{7}\right.$ cells $)$ and run over a fresh LS column. This separation resulted in less than $1 \% \mathrm{CD} 25^{+}$cells in the $\mathrm{CD} 4^{+} \mathrm{CD} 25^{-}$fraction and greater than $95 \%$ purity in the $\mathrm{CD} 25^{+} \mathrm{T}$ cell subset.

FACS sorting of T cell subsets from peripheral blood. PBMCs were isolated from peripheral blood as before, and CD4 T cells were purified by magnetic separation as above. Purified $\mathrm{CD}_{4}^{+} \mathrm{T}$ cells were stained with a mixture of antibodies consisting of anti-CD4-PerCP (PerCP, peridinin-chlorophyll-protein complex) (BD), anti-CD45RA-FITC (BD Biosciences - Pharmingen), and anti-CD25-PE (Dako) for 30 minutes on ice, washed in PBS/2\% BSA, filtered, and sorted on a MoFlo flow cytometer (Dako). Gates were set so that purified $\mathrm{CD} 4{ }^{+} \mathrm{CD} 25^{\text {hi }}$ cells represented the brightest $2 \%$ of total CD4 population; both $\mathrm{CD} 4^{+} \mathrm{CD} 25^{\text {hi }}$ and $\mathrm{CD} 4^{+} \mathrm{CD} 25^{-}$populations were collected from the CD45RA- fraction and were therefore designated as CD45RO ${ }^{+}$ for clarity (Supplemental Figure 4). Naive $\mathrm{CD} 4^{+} \mathrm{CD} 45 \mathrm{RA}^{+}$cells were also collected in some experiments.

Phenotype analysis and telomere measurement. For phenotypic analysis, PBMCs were stained with a combination of antibodies including anti- 
CD4-PerCP, anti-CD25-PE, anti-CD45RB-FITC, anti-CD45RA-APC, anti-Bcl-2-FITC, and anti-CTLA4-APC. TCR V $\beta$ repertoire usage was investigated using the IOTest Beta Mark kit according to the manufacturer's recommendations (Beckman Coulter). Gates were set so that the $\mathrm{CD} 4^{+} \mathrm{CD} 25^{-}$population was based on the isotype control while the $\mathrm{CD} 25^{\mathrm{hi}}$ population was determined relative to the low intensity of CD25 staining found on non-CD4 $\mathrm{T}$ cells. The population between these 2 gates was considered CD25 $5^{\text {int }}$. Cells were analyzed using a FACSCalibur with CellQuest software, version $3.3(\mathrm{BD})$.

Foxp3 expression was analyzed by FACS according to the protocol described by Roncador et al. (54). In brief, fresh PBMCs were washed in PBS, fixed in $1 \mathrm{ml}$ of PBS with $1 \%$ paraformaldehyde and $0.05 \%$ Tween, and kept overnight at $4{ }^{\circ} \mathrm{C}$. Cells were treated twice with $0.5 \mathrm{ml}$ of DNase at 100 Kunitz $/ \mathrm{ml}$ according to manufacturer's instructions (Sigma-Aldrich). Cells were incubated with mouse anti-human Foxp3 (clone150D/E4, a kind gift from Alison Banham, University of Oxford, Oxford, United Kingdom) for 1 hour at room temperature and washed with FACS buffer (PBS, 3\% FCS, $0.5 \%$ Tween-20, and $0.05 \%$ azide). Foxp3 staining was detected by staining with Alexa Fluor 488 goat anti-mouse IgG (Molecular Probes; Invitrogen). Cell-surface staining was performed using anti-CD4-PerCP (BD) and antiCD25-PE (Dako) for 20 minutes at room temperature.

For telomere length measurement, we used a 3-color flow-FISH technique (31). PBMCs were stained with anti-CD4-biotin (Beckman Coulter) followed by streptavidin-Cy3 (Cedarlane Laboratories Ltd.) and either antiCD25-FITC or anti-CD45RO-FITC. Following fixation, cells were hybridized with $0.75 \mu \mathrm{g} / \mathrm{ml}$ of the peptide nucleic acid telomeric $\left(\mathrm{C}_{3} \mathrm{TA}_{2}\right)_{3}$ probe conjugated to Cy5. Samples were heated for 10 minutes at $82^{\circ} \mathrm{C}$, rapidly cooled on ice, and hybridized for 1 hour at room temperature in the dark. Samples were then washed and analyzed immediately by flow cytometry. All staining was performed in triplicate, and telomere lengths for total $\mathrm{CD} 4, \mathrm{CD}^{+} \mathrm{CD} 45 \mathrm{RO}^{+}$, and $\mathrm{CD} 4{ }^{+} \mathrm{CD} 25^{\text {hi }}$ subsets were obtained.

Phenotypic analysis of $C M V$-specific $C D 4^{+}$cells. PBMCs from CMV-seropositive donors were stimulated with CMV lysate overnight in the presence of $5 \mu \mathrm{g} / \mathrm{ml}$ brefeldin A. Cells were stained with CD4-PerCP and a range of V $\beta$ antibodies from the IOTest Beta Mark kit, fixed, permeabilized, and stained with IFN- $\gamma$ APCs. For phenotypic analysis of a particular V $\beta$, PBMCs were costained with the appropriate $\mathrm{V} \beta$ antibody, then either stained with $\mathrm{CD} 27$ and $\mathrm{CD} 28$, stained with $\mathrm{Bcl}-2$, or hybridized with the telomere probe.

Proliferation and suppression assays. Purified CD4 T cell subsets $\left(5 \times 10^{4} /\right.$ well $)$ were stimulated in triplicate wells with $\mathrm{Ag}$ (purified protein derivative or tetanus toxoid) and irradiated (40 Gy) autologous PBMCs as APCs $\left(5 \times 10^{4}\right.$ / well) in 96-well round-bottom plates (Nunc). For suppression assays, $5 \times 10^{4} \mathrm{CD}^{+} \mathrm{CD} 25^{-} \mathrm{T}$ cells were stimulated in the absence or presence of $\mathrm{CD} 4{ }^{+} \mathrm{CD} 25^{+} \mathrm{T}$ cells at responder/suppressor ratios of 1:0 and 1:1. As a control, an equal number of $\mathrm{CD} 4^{+} \mathrm{CD} 25^{-}$cells were added. Cells were cultured in RPMI-1640 medium (Invitrogen) supplemented with 1\% penicillin/streptomycin, $1 \% \mathrm{~L}$-glutamine, and $10 \%$ human $\mathrm{AB}$ serum (all Sigma-Aldrich) for 6-7 days. During the last 18 hours of culture, ${ }^{3} \mathrm{H}$-thymidine was added at $1 \mu \mathrm{Ci} /$ well. For polyclonal stimulation, anti-CD3 (OKT3) was used and was immobilized on flat-bottom 96 -well plates at 0.1 or $0.5 \mu \mathrm{g} / \mathrm{ml}$ in the presence of irradiated autologous PBMCs as APCs. Proliferation was measured at 72 hours. Proliferative responses are expressed as mean ${ }^{3} \mathrm{H}$-thymidine incorporation (cpm) of triplicate wells \pm SEM.

Assessment of clonality by heteroduplex analysis. The clonal composition of purified $\mathrm{CD} 4{ }^{+} \mathrm{RO}^{+} \mathrm{CD} 25^{-}$and $\mathrm{CD} 4{ }^{+} \mathrm{RO}^{+} \mathrm{CD} 25^{\text {hi }} \mathrm{T}$ cell populations FACS sorted from PBMCs was determined by comparing the CDR3 region of different TCR V $\beta$ families. PCR was performed on V $\beta$ s $1-24$, including V $\beta$ 5.1 and 5.2 and $V \beta 13.1$ and 13.2 families, using specific $V \beta$ and common $\mathrm{C} \beta$ primers, as described extensively elsewhere (33). Each sample PCR was mixed with V $\beta$-matched carrier DNA, denatured, and reannealed. The product was run on a $12 \%$ polyacrylamide gel, which was then blotted and hybridized with a probe to the external $C \beta$ region of the carrier. The probe was detected using anti-digoxigenin-alkaline phosphatase Fab fragments and CDP-Star substrate (Roche Diagnostics). Identical clones within CD4 ${ }^{+}$ $\mathrm{T}$ cell populations were detected as heteroduplex bands with identical migration patterns (33). The presence of heteroduplexes has previously been shown to relate to the presence of an expanded clone as determined by the sequencing of PCR product (33).

Telomerase activity measurement. Telomerase activity was measured using the telomeric repeat amplification protocol (TRAP, TRAPeze Telomerase Detection Kit; Intergen Company). In brief, telomerase present in a test cell extract extends a template with telomeric repeats and, following PCR amplification, generates a ladder of products with 6-bp increments starting at 50 nucleotides. FACS-sorted $\mathrm{CD} 4{ }^{+} \mathrm{CD} 25^{\text {hi }}$ and $\mathrm{CD} 4{ }^{+} \mathrm{CD} 25$ were stimulated in vitro with anti-CD3/anti-CD28-coated beads for 4 days. Samples were collected by snap freezing of cells from in vitro cultures. Absolute numbers of $\mathrm{CD}^{+} \mathrm{Ki} 67^{+}$cells in each sample were enumerated using TruCOUNT Tubes (BD) and Ki67 analysis. PCR was performed with samples adjusted to $500 \mathrm{Ki} 67^{+} \mathrm{T}$ cells per reaction. The negative control contains the PCR mix without cell extract, and the positive control contains an extract of a telomerase-positive tumor cell line. TSR8 is a telomeric template that is used as a PCR control.

Glucose labeling and turnover analysis. Subjects received deuterium-labeled glucose (6,6- $\mathrm{D}_{2}$-glucose, $0.6 \mathrm{~g} / \mathrm{kg}$; Cambridge Isotope Laboratories Inc.) in half-hourly aliquots over a 10 -hour period during which subjects received small, low-energy meals at 2.5-hour intervals as previously described (55). In order to assess constancy of labeling, blood samples were taken approximately every 2 hours during glucose administration, and plasma glucose enrichment was measured following derivatization to the aldononitrile acetate derivative by gas chromatography mass spectrometry (monitoring ions m/z 328 and 330 by SIM, Agilent 5973/6890, HP-225 column; Agilent Technologies). The mean enrichment for the labeling period was calculated form the area under the curve.

For estimation of deuterium enrichment in cellular DNA, $50 \mathrm{ml}$ heparinized blood samples were taken at $3,4,10$, and 21 days after labeling. Enrichment of deuterium in DNA from purified cell populations was assayed essentially as described previously (56). In brief, cellular DNA was extracted and digested enzymatically to deoxynucleosides. The deoxyadenosine fraction was taken as a representative deoxynucleoside and analyzed as the aldononitrile acetate derivative in triplicate by gas chromatography mass spectrometry as above (except monitoring ions 198 and 200) (56). The minimum quantity of cells that can be analyzed in this way is $2 \times 10^{5}$, equivalent to about $1 \mathrm{mg}$ of DNA; typical retrieval amounts for $\mathrm{CD} 4{ }^{+} \mathrm{CD} 45 \mathrm{RA}^{-} \mathrm{CD} 25^{\text {hi }} \mathrm{T}$ cells, the smallest population that was sorted from $50 \mathrm{mls}$ of blood, were $3 \times 10^{5}$ cells.

Results were expressed as the fraction of labeled cells $(F)$, expressed as equivalents of a 1-day labeling period, present at each sampling point, where $F$ is equal to the ratio of the enrichment of deuterium in DNA $(E)$ to the precursor enrichment $(b)$ (taken as mean plasma glucose corrected for intracellular dilution by a factor of 0.65$)(24)$, so that $F=E / b$. The magnitude of the peak value for $F$ represents a measure of the cellular proliferation rate.

Data was modeled as previously described (56) (SigmaPlot, version 8.02; SPSS) to estimate the rate of proliferation during labeling, $p$, and the rate of loss of labeled cells, $d^{*}$, by nonlinear least squares regression to the following formulas: $F(t)=p / d^{*}\left(1-\mathrm{e}^{-d^{*} t}\right)$, where $t \leq \tau$ during the labeling period, and $F(t)=p / d^{*}\left(1-e^{-d^{*} \tau}\right) \mathrm{e}^{-d^{*}(t-\tau)}$, where $t>\tau$ during the labeling period, and where $t$ is time and $\tau$ is the length of the labeling period. In this model, constancy of pool size has been assumed, but no assumption of equality between $p$ and $d^{*}$ has been made: $p$ represents the average proliferation 
rate of the whole population whereas $d^{*}$ refers only to labeled cells (i.e., cells which divided during the labeling period). For a kinetically heterogeneous population, even one at steady state, these 2 rates will not be the same, as discussed $(2,56)$. Proliferation expressed as $T_{2}$ and disappearance as half-life $\left(t_{1 / 2}\right)$ were calculated as $\ln 2 / p$ and $\ln 2 / d^{*}$, respectively. Statistical comparisons between cell types were made by ANOVA with post hoc Tukey-Kramer test and between paired data from CD25 ${ }^{\text {hi }}$ and $\mathrm{CD} 25^{-}$cell populations by 2-tailed, paired Student's $t$ test.

Statistics. Statistical significance was evaluated using a Student's 2-tailed $t$ test and, where appropriate, a 2-tailed, paired Student's $t$ test. Differences were considered significant at $P<0.05$.

\section{Acknowledgments}

We thank Alison Banham for the generous gift of Foxp3 antibody, Katie Lacy for organizing blood sample collection, Becca Asquith for advice on modeling, and Andrew Worth for expert cell sorting. This work was supported by grants from Biotechnology and Biological Sciences Research Council (to M. Vukmanovic-Stejic), Dermatrust (to A. McQuaid), Research into Ageing (to J.E. Cook and J.E. Masters), and The Henry Smith Charity (to J.M. Fletcher). Y. Zhang received support from the Medical Research Council and the Edward Jenner Institute for Vaccine Research.

Received for publication April 27, 2006, and accepted in revised form July 11, 2006.

Address correspondence to: A.N. Akbar, Department of Immunology and Molecular Pathology, Windeyer Institute, 46 Cleveland Street, London W1T 4JF, United Kingdom. Phone: 44-2076799214; Fax: 44-20-76799545; E-mail: a.akbar@ucl.ac.uk.
1. Michie, C.A., McLean, A., Alcock, C., and Beverley, P.C. 1992. Lifespan of human lymphocyte subsets defined by CD45 isoforms. Nature. 360:264-265.

2. Macallan, D.C., et al. 2004. Rapid turnover of effector-memory CD4(+) T cells in healthy humans. J. Exp. Med. 200:255-260.

3. Shevach, E.M. 2002. CD4+ CD25+ suppressor T cells: more questions than answers. Nat. Rev. Immunol. 2:389-400.

4. Sakaguchi, S. 2004. Naturally arising CD4+ regulatory $t$ cells for immunologic self-tolerance and negative control of immune responses. Annu. Rev. Immunol. 22:531-562.

5. Coombes, J.L., Robinson, N.J., Maloy, K.J., Uhlig, H.H., and Powrie, F. 2005. Regulatory T cells and intestinal homeostasis. Immunol. Rev. 204:184-194.

6. Picca, C.C., and Caton, A.J. 2005. The role of selfpeptides in the development of CD4+ CD25+ regulatory T cells. Curr. Opin. Immunol. 17:131-136.

7. Hsieh, C.S., Zheng, Y., Liang, Y., Fontenot, J.D., and Rudensky, A.Y. 2006. An intersection between the self-reactive regulatory and nonregulatory $\mathrm{T}$ cell receptor repertoires. Nat. Immunol. 7:401-410.

8. Apostolou, I., and von Boehmer, H. 2004. In vivo instruction of suppressor commitment in naive $\mathrm{T}$ cells. J. Exp. Med. 199:1401-1408.

9. Cobbold, S.P., et al. 2004. Induction of foxP3+ regulatory $\mathrm{T}$ cells in the periphery of $\mathrm{T}$ cell receptor transgenic mice tolerized to transplants. J. Immunol. 172:6003-6010.

10. Thorstenson, K.M., and Khoruts, A. 2001. Generation of anergic and potentially immunoregulatory CD25+CD $4 \mathrm{~T}$ cells in vivo after induction of peripheral tolerance with intravenous or oral antigen. J. Immunol. 167:188-195.

11. Krueger, A., Fas, S.C., Baumann, S., and Krammer, P.H. 2003. The role of CD95 in the regulation of peripheral T-cell apoptosis. Immunol. Rev. 193:58-69.

12. Marrack, P., and Kappler, J. 2004. Control of T cell viability. Annu. Rev. Immunol. 22:765-787.

13. Akbar, A.N., and Salmon, M. 1997. Cellular environments and apoptosis: tissue microenvironments control activated T-cell death. Immunol. Today. 18:72-76.

14. Hodes, R.J., Hathcock, K.S., and Weng, N.P. 2002. Telomeres in T and B cells. Nat. Rev. Immunol. 2:699-706.

15. Akbar, A.N., and Fletcher, J.M. 2005. Memory T cell homeostasis and senescence during aging. Curr. Opin. Immunol. 17:480-485.

16. Akbar, A.N., Beverley, P.C., and Salmon, M. 2004. Will telomere erosion lead to a loss of T-cell memory? Nat. Rev. Immunol. 4:737-743.

17. Walker, L.S., Chodos, A., Eggena, M., Dooms, H., and Abbas, A.K. 2003. Antigen-dependent proliferation of CD4+ CD25+ regulatory T cells in vivo. J. Exp. Med. 198:249-258.
18. Fisson, S., et al. 2003. Continuous activation of autoreactive CD4+CD25+ regulatory T cells in the steady state. J. Exp. Med. 198:737-746.

19. Klein, L., Khazaie, K., and von Boehmer, H. 2003. In vivo dynamics of antigen-specific regulatory $\mathrm{T}$ cells not predicted from behavior in vitro. Proc. Natl. Acad. Sci. U. S. A. 100:8886-8891.

20. Kipling, D., and Cooke, H.J. 1990. Hypervariable ultra-long telomeres in mice. Nature. 347:400-402.

21. Baecher-Allan, C., Brown, J.A., Freeman, G.J., and Hafler, D.A. 2001. CD4+CD25high regulatory cells in human peripheral blood. J. Immunol. 167:1245-1253.

22. Hellerstein, M., et al. 1999. Directly measured kinetics of circulating $\mathrm{T}$ lymphocytes in normal and HIV-1-infected humans. Nat. Med. 5:83-89.

23. Sereti, I., et al. 2005. In vivo expansion of $\mathrm{CD}^{+}{ }^{+} \mathrm{CD} 45 \mathrm{RO}^{-} \mathrm{CD} 25^{+} \mathrm{T}$ cells expressing foxP 3 in IL-2-treated HIV-infected patients. J. Clin. Invest. 115:1839-1847. doi:10.1172/JCI24307.

24. Macallan, D.C., et al. 1998. Measurement of cell proliferation by labeling of DNA with stable isotopelabeled glucose: studies in vitro, in animals, and in humans. Proc. Natl. Acad. Sci. U. S. A. 95:708-713.

25. Taams, L.S., et al. 2001. Human anergic/suppressive CD4(+)CD25(+) T cells: a highly differentiated and apoptosis-prone population. Eur. J. Immunol. 31:1122-1131.

26. Akbar, A.N., et al. 1993. The significance of low bcl-2 expression by CD45RO T cells in normal individuals and patients with acute viral infections. The role of apoptosis in T cell memory. J. Exp. Med. 178:427-438.

27. Vella, A.T., Dow, S., Potter, T.A., Kappler, J., and Marrack, P. 1998. Cytokine-induced survival of activated T cells in vitro and in vivo. Proc. Natl. Acad. Sci. U. S. A. 95:3810-3815.

28. Grayson, J.M., Zajac, A.J., Altman, J.D., and Ahmed, R. 2000. Cutting edge: increased expression of $\mathrm{Bcl}-2$ in antigen-specific memory CD8+ T cells. J. Immunol. 164:3950-3954.

29. Harley, C.B., Futcher, A.B., and Greider, C.W. 1990. Telomeres shorten during ageing of human fibroblasts. Nature. 345:458-460.

30. Rufer, N., et al. 1999. Telomere fluorescence measurements in granulocytes and $\mathrm{T}$ lymphocyte subsets point to a high turnover of hematopoietic stem cells and memory T cells in early childhood. J. Exp. Med. 190:157-167.

31. Reed, J.R., et al. 2004. Telomere erosion in memory $\mathrm{T}$ cells induced by telomerase inhibition at the site of antigenic challenge in vivo. J. Exp. Med. 199:1433-1443.

32. Fletcher, J.M., et al. 2005. Cytomegalovirus-specific CD4+ T cells in healthy carriers are continuously driven to replicative exhaustion. J. Immunol. 175:8218-8225.

33. Maini, M.K., et al. 1998. A comparison of two techniques for the molecular tracking of specific T-cell responses; CD4+ human T-cell clones persist in a stable hierarchy but at a lower frequency than clones in the CD8+ population. Immunology. 94:529-535.

34. Gregg, R., et al. 2005. The number of human peripheral blood CD4+ CD25high regulatory $\mathrm{T}$ cells increases with age. Clin. Exp. Immunol. 140:540-546.

35. Murphy, K.M., and Reiner, S.L. 2002. The lineage decisions of helper T cells. Nat. Rev. Immunol. 2:933-944.

36. Chen, W., et al. 2003. Conversion of peripheral CD4+CD25- naive T cells to CD4+CD25+ regulatory $\mathrm{T}$ cells by TGF-beta induction of transcription factor Foxp3. J. Exp. Med. 198:1875-1886.

37. Kretschmer, K., et al. 2005. Inducing and expanding regulatory $\mathrm{T}$ cell populations by foreign antigen. Nat. Immunol. 6:1219-1227.

38. Barrat, F.J., et al. 2002. In vitro generation of interleukin 10-producing regulatory $\mathrm{CD} 4(+) \mathrm{T}$ cells is induced by immunosuppressive drugs and inhibited by T helper type 1 (Th1)- and Th2-inducing cytokines. J. Exp. Med. 195:603-616.

39. Chen, Y., Kuchroo, V.K., Inobe, J., Hafler, D.A., and Weiner, H.L. 1994. Regulatory T cell clones induced by oral tolerance: suppression of autoimmune encephalomyelitis. Science. 265:1237-1240.

40. Lombardi, G., Sidhu, S., Batchelor, R., and Lechler, R. 1994. Anergic T cells as suppressor cells in vitro. Science. 264:1587-1589.

41. Taams, L.S., et al. 2002. Antigen-specific T cell suppression by human $\mathrm{CD} 4+\mathrm{CD} 25+$ regulatory $\mathrm{T}$ cells. Eur. J. Immunol. 32:1621-1630.

42. Chai, J.G., et al. 1999. Anergic T cells act as suppressor cells in vitro and in vivo. Eur. J. Immunol. 29:686-692.

43. Walker, M., et al. 2003. Induction of FoxP3 and acquisition of T regulatory activity by stimulated human $\mathrm{CD}^{+} \mathrm{CD} 25^{-} \mathrm{T}$ cells. J. Clin. Invest. 112:1437-1443. doi:10.1172/JCI200319441.

44. Akdis, M., et al. 2004. Immune responses in healthy and allergic individuals are characterized by a fine balance between allergen-specific $T$ regulatory 1 and T helper 2 cells. J. Exp. Med. 199:1567-1575.

45. Viglietta, V., Baecher-Allan, C., Weiner, H.L., and Hafler, D.A. 2004. Loss of functional suppression by CD $4+\mathrm{CD} 25+$ regulatory $\mathrm{T}$ cells in patients with multiple sclerosis. J. Exp. Med. 199:971-979.

46. Ling, E.M., et al. 2004. Relation of CD4+CD25+ regulatory $\mathrm{T}$-cell suppression of allergen-driven T-cell activation to atopic status and expression of allergic disease. Lancet. 363:608-615.

47. Ehrenstein, M.R., et al. 2004. Compromised function of regulatory $\mathrm{T}$ cells in rheumatoid arthritis and reversal by anti-TNFalpha therapy. J. Exp. Med. 200:277-285.

48. Liyanage, U.K., et al. 2002. Prevalence of regu- 
latory $\mathrm{T}$ cells is increased in peripheral blood and tumor microenvironment of patients with pancreas or breast adenocarcinoma. J. Immunol. 169:2756-2761.

49. D'Cruz, L.M., and Klein, L. 2005. Development and function of agonist-induced CD25+Foxp $3+$ regulatory $\mathrm{T}$ cells in the absence of interleukin 2 signaling. Nat. Immunol. 6:1152-1159.

50. Fontenot, J.D., Rasmussen, J.P., Gavin, M.A., and Rudensky, A.Y. 2005. A function for interleukin 2 in Foxp3-expressing regulatory T cells. Nat. Immu- nol. 6:1142-1151.

51. Knoechel, B., Lohr, J., Kahn, E., Bluestone, J.A., and Abbas, A.K. 2005. Sequential development of interleukin 2-dependent effector and regulatory $\mathrm{T}$ cells in response to endogenous systemic antigen. J. Exp. Med. 202:1375-1386.

52. Jonuleit, H., et al. 2002. Infectious tolerance: human $\mathrm{CD} 25(+)$ regulatory $\mathrm{T}$ cells convey suppressor activity to conventional CD4(+) T helper cells. J. Exp. Med. 196:255-260.

53. Pawelec, G., et al. 2005. Human immunosenes- cence: is it infectious? Immunol. Rev. 205:257-268. 54. Roncador, G., et al. 2005. Analysis of FOXP3 protein expression in human CD4+CD25+ regulatory $\mathrm{T}$ cells at the single-cell level. Eur. J. Immunol. 35:1681-1691.

55. Ghattas, H., et al. 2005. Measuring lymphocyte kinetics in tropical field settings. Trans. R. Soc. Trop. Med. Hyg. 99:675-685.

56. Macallan, D.C., et al. 2003. Measurement and modeling of human T cell kinetics. Eur. J. Immunol. 33:2316-2326. 